\title{
An Overview of Hydropower Reservoirs in Brazil: Current Situation, Future Perspectives and Impacts of Climate Change
}

\author{
Viviane de Souza Dias ${ }^{1}$, Marta Pereira da Luz $^{2, *}$, Gabriela M. Medero ${ }^{3}$ and \\ Diego Tarley Ferreira Nascimento ${ }^{4}$
}

1 Industrial and Systems Engineering Postgraduate Program-MEPROS, Pontifical Catholic University of Goiás, Av. Universitária 1.440, Setor Universitário, Goiânia CEP 74605-010, Goiás, Brazil; engvivianedias@gmail.com

2 Eletrobras Furnas, Industrial and Systems Engineering Postgraduate Program-MEPROS, Pontifical Catholic University of Goiás, BR153, km 510, Zona Rural, Aparecida de Goiânia CEP 74923-650, Goiás, Brazil

3 School of Energy, Geoscience, Infrastructure and Society, Heriot-Watt University, Edinburgh EH14 4AS, UK; G.Medero@hw.ac.uk

4 Geography, Teacher and Humanities Training School, Pontifical Catholic University of Goiás, Av. Universitária 1.440, Setor Universitário, Goiânia CEP 74605-010, Goiás, Brazil; diego.tarley@gmail.com

* Correspondence: martaluz@furnas.com.br; Tel.: +55-062-3239-6550

Received: 13 March 2018; Accepted: 25 April 2018; Published: 3 May 2018

\begin{abstract}
Global climate change, related to the greenhouse gases emission, impacts hydroelectric power generation mainly due to the increase in air temperature and changes in the precipitation patterns. As a consequence, it affects basin evapotranspiration process, runoff, sediment transport as well as evaporation of reservoirs. This study analysed the current and future Brazilian context of hydroelectric reservoirs and investigated the potential impacts of climate change on hydropower generation and possible mitigation adjustments, giving relevant examples from around the world. Moreover, it is key to consider other factors that influence the availability of water resources such as: (a) upstream development of reservoirs, mainly the development of agricultural systems, which can contribute to increased water demand; (b) changes in land use, which can have an impact on soil degradation and sediment transport. Hydroelectric dams are a possible alternative to mitigate the impacts of climate change considering that those impacts could generate the need of adaptive actions. The assessment of climate change impacts' projections anticipates possible future scenarios and can assist in strategic planning together with the definition of adaptive operational policies.
\end{abstract}

Keywords: hydropower plants; climate changes; reservoirs; Brazil

\section{Introduction}

Hydroelectric plants are the main sources of electricity in some countries (e.g., Paraguay, Norway, Brazil, Austria and Canada). Hydropower contributes about $85 \%$ of global renewable electricity $[1,2]$. It is the main source of renewable energy in South America, followed by biofuels [3]. In several regions of the world (e.g., Southeast Asia and South America), the hydroelectric plants are one of the pillars for the production of renewable energy, but, at the same time, they are vulnerable to the impacts of climate change [4]. These changes are causing the majority of the variations in hydroelectric potential [5]. Other factors, such as changes in land use and demand for upstream irrigation, can also influence water availability for energy generation [5-7].

Brazil has one of the largest hydroelectric potentials and it is believed that hydroelectricity will continue to play an important role in the next ten years [8]. In the country, $80 \%$ of the energy generated 
comes from renewable sources [9]. The Brazilian energy matrix is composed mainly of hydroelectric plants $(60.9 \%)$, followed by fossil fuels $(16.11 \%)$, biomass $(8.74 \%)$, eolic $(7.52 \%)$, import $(4.91 \%)$, nuclear $(1.20 \%)$ and solar $(0.61 \%)$ [10]. The 85 solar power plants account for 1,021,602 $\mathrm{kW}$ of the installed capacity, and only $0.61 \%$ of the energy matrix [10]. Even though the country has areas with high solar irradiation, there are no available technologies for its deployment, showing a clear need for investments in national technologies [11]. Most of the equipment required for the installation of solar photovoltaic and concentrated solar thermal plants is imported, which implies high costs [12].

Regarding energy sources, hydroelectric plants are likely to be more affected by changes in annual and seasonal precipitation as well as temperature increase $[13,14]$, with smaller impact on other energy system sources [15]. Two opposite sides must be considered in terms of energy generation and climate change: on one hand, there is energy generation producing emissions (including hydroelectric; through the decomposition of organic matter in reservoirs), which requires mitigation strategies; and, on the other hand, the impact of climate change on renewable energy sources, requiring adaptation strategies [13].

Water resource use for generation of energy is dependent on hydrological and climatic conditions [4-6,8,15-19]. Global warming may influence the intensity and duration of rainfall, the discharge volume of rivers, the increased evaporation rate of reservoirs and the amount of evapotranspiration of plants [20]. Thus, these factors interfere in the water availability for energy generation and may trigger indirect effects such as changes in land use and an increased demand for irrigation [18].

Several impacts of climate change on hydroelectric reservoirs can be considered: hydrological changes, variation in sediment load due to flooding, variation in volume and river flow due to changes in precipitation, and the occurrence of extreme events (e.g., droughts and floods) that can generate the need for dam design and safety improvements $[1-6,8]$.

Hydropower reservoirs are less susceptive to climate change than run-of-river schemes due to its storage capacity as well as being less seasonal flow dependent [18]. This resilience depends on dry season duration [13]. The changes in the flow affect the level of reservoir and, consequently, the capacity of energy generation $[18,19]$. In Brazil, there are expectations that future hydroelectric installations will be of run-of-river due to environmental restrictions for the construction of large reservoirs, resulting in the use of the total installed capacity of water flow schemes only during the rainy season. In the dry season, other plants, such as thermoelectric plants, would need to be used to meet the energy demand [21].

Climate change must be taken into account in the process of water resources planning and management, so that measures are taken to adapt to future climate scenarios [6]. Adaptation strategies for the operation of reservoirs should be implemented $[5,16,22]$, since hydroelectric plants are fundamental for electricity in Brazil [19].

Through a review of the literature, this study aims:

- $\quad$ To provide an overview of the current state of hydroelectric plants in Brazil, focusing on reservoir plant types, providing insights into recent policies for the development of hydropower (Section 2);

- To assess the potential for new hydroelectric plants in the country (Section 3);

- To put the current state of hydroelectric plants in Brazil into context in comparison with other countries (Section 4);

- To present the possible impacts of climate change on hydroelectric power generation. To analyse and compare methodologies and results of studies that evaluate the impact of climate change on energy generation by hydroelectric reservoirs (Section 5);

- To identify measures to adapt to future climate scenarios that have been the focus of studies in Brazil and in other countries. (Section 6);

- To present a framework directed to the study of climatic and environmental impact on the generation of hydroelectricity (Section 7). 


\section{Current Situation of Brazilian Hydroelectric Plants}

Brazil has a great hydroelectric potential, totalling $101,268,561 \mathrm{~kW}$, which corresponds to $60.9 \%$ of the energy matrix. There are 1313 operating plants ranging from hydroelectric generation centrals (with up to $1 \mathrm{MW}$ of power installed), small hydropower plants (between 1.1 MW and $30 \mathrm{MW}$ ) and hydroelectric power plants (with more than $30 \mathrm{MW}$ ). The 218 hydroelectric power plants (HPP) are responsible for $60.5 \%$ of the total installed capacity in the country, adding up to $95,619,468 \mathrm{~kW}$. The small hydroelectric plants (SHP), 428 in total, answer for 3.2\% of the total installed power. The 667 hydroelectric generation centrals (HGC) in operation account for only $0.4 \%$ of the installed power [23].

The largest Brazilian hydroelectric power plant is Itaipu, located in the Paraná River [8]. After its construction, the Belo Monte hydroelectric in the Amazon basin will be the third largest hydroelectric power plant in the world $(11,233 \mathrm{MW})$. The second largest is Itaipu, producing $14,000 \mathrm{MW}$, and the largest in the world is the Three Gorges hydroelectric plant in China, producing 22,500 MW [2,8]. The main Brazilian plants with regularization reservoirs are presented in Table 1 and sorted by region and importance in useful volume.

Table 1. Main Brazilian hydropower plants with reservoirs—-based on data from [24].

\begin{tabular}{|c|c|c|c|c|c|}
\hline Region & Name & River & Power (MW) & $\begin{array}{l}\text { Useful Volume } \\
\qquad\left(\mathrm{km}^{3}\right)\end{array}$ & $\begin{array}{l}\text { Storable Useful Volume } \\
\left(\mathrm{km}^{3} / \mathrm{GW}\right)\end{array}$ \\
\hline North & Tucurui & Tocantins & 8370 & 38.98 & 4.7 \\
\hline Northeast & Sobradinho & São Francisco & 1050 & 28.67 & 27.3 \\
\hline Southeast/Midwest & Serra da Mesa & Tocantins & 1275 & 43.25 & 33.9 \\
\hline Southeast/Midwest & Furnas & Grande & 1312 & 17.22 & 13.1 \\
\hline Southeast/Midwest & Emborcaçao & Paranaiba & 1192 & 13.06 & 11.0 \\
\hline Southeast/Midwest & Itumbiara & Paranaiba & 2280 & 12.45 & 5.5 \\
\hline Southeast/Midwest & Nova Ponte & Araguari & 510 & 10.38 & 20.4 \\
\hline South & Foz do Areia & Iguaçu & 1676 & 5.80 & 3.8 \\
\hline South & Passo Real & Jacui & 158 & 3.36 & 21.2 \\
\hline
\end{tabular}

The Serra da Mesa hydroelectric power plant on the Tocantins River has the highest useful volume, at $43.25 \mathrm{~km}^{3}$; followed by the Tucurui plant, in the same river, at $38.98 \mathrm{~km}^{3}$, which stands out in terms of installed power at $8370 \mathrm{MW}$ [24]. Usually the levels of the reservoirs are higher in the summer, from December to March (more abundant rainy period), and lower between April and November, when there is the dry season [8].

Recent studies addressed the current situation of SHP in Brazil, exposing regulations and policies for the growth of the number of plants and the perspectives for the sector [25]. Brazilian SHPs are expanding due to their characteristics of small area occupancy and minor environmental impact, besides the possibility of installation closer to the places of consumption, which reduces the loss of energy in the transmission and, consequently, results in a reduction of costs for the consumer.

The main Brazilian hydroelectric reservoirs are in the Paraná river basin. The concentration of hydroelectric power plants is higher in the Midwest, South and Southeast regions (Figure 1). The Southwest region accounts for 70\% of the energy storage capacity. The largest hydroelectric reservoirs are installed near the regions of greatest demand. When full, these reservoirs can store energy to meet the demands for five months, a much shorter period than that observed in the 1970s, when the energy stored in the reservoirs, at maximum capacity, could meet the demand for three or four years [26]. These changes arise as a result to the increase in energy demand caused by population growth, in addition to climate and environmental changes. 


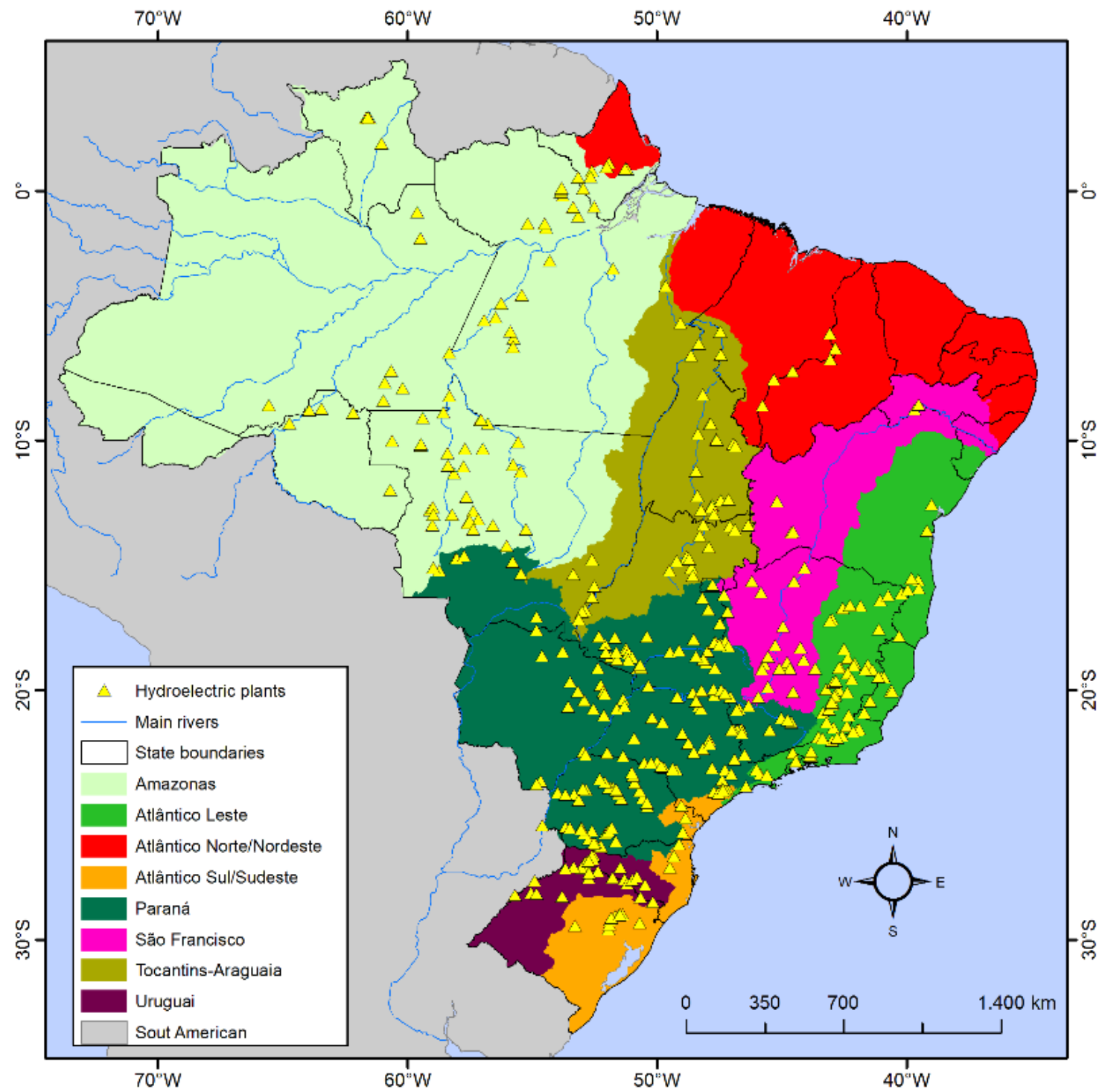

Figure 1. Brazilian hydroelectric plants by hydrographic basin—based on data from [27].

\section{Recent Policies for the Development of Hydropower}

In Brazil, renewable energy sources are considered fundamental for sustainable development [28]. Two strategies with regard to the energy sector have been incorporated in Brazil, one focusing on a clean and renewable energy matrix, mainly hydroelectric, and the other promoting efficient use and conservation [11]. However, the country needs to review current energy policies in the context of economic growth and also to consider climate change, with investments in energy efficiency, renewable sources and the necessary technological improvements [29].

Brazil has opted to increase energy security levels, increase energy generation capacity, and, with this expansion, environmental and social problems have arisen. In order to avoid greater environmental impacts, the main strategy goes towards new projects for run-of-river. However, this policy ends up affecting the generation of energy during dry periods, due to lesser river flow [30]. To achieve energy security, the country has invested in hydroelectric and thermal plants, in order to compensate for the lower generation of hydropower during dry periods [29].

In run-of-river schemes, energy costs are higher due to the possibility of inactivity in dry periods caused by the absence of a reservoir. The construction time is shorter, on average two years. With regard to environmental impacts, the cumulative effects of several run-of-river installed in the same basin 
must be considered [8]. In addition, the implementation of run-of-river hydropower plants can also contribute to the increase of emissions indirectly, with the need to complement the hydroelectric potential with thermoelectric plants [29].

In contrast, large reservoirs maximise electricity production, ensuring greater energy security of the system during periods of drought [5,31]. However, some factors may affect the decision on the construction of hydroelectric reservoirs such as: building time; greenhouse gas emissions; fragmentation of the rivers; changes in water quality; relocating or displacing humans; interference in migration and spawning fish.

The average building time of large dams is 8.6 years [32]. Since the 1990s, possible emissions from reservoirs have attracted the attention of several researchers [33-36]. Even though it is a renewable source of energy, there are potential greenhouse gas emissions from reservoirs, such as: methane $\left(\mathrm{CH}_{4}\right)$, nitrous oxide $\left(\mathrm{N}_{2} \mathrm{O}\right)$, and carbon dioxide $\left(\mathrm{CO}_{2}\right)$. Large amounts of organic matter remain in the reservoir when the area is flooded, leading to the production of these gases. One of the major concerns is the emission of methane [37]. According to Zarfl et al. [38], the quantitative emissions depend on how water is released in dams. The release of deep water contributes most significantly for emissions.

Studies carried out in areas in riparian and grassland environments of the Belo Monte hydroelectric complex (Pará) indicate that the most significant concentrations were $\mathrm{CO}_{2}$ with a daily mean value of $10,448.41 \pm 3036.48 \mathrm{mg} \mathrm{m}^{-2}$ for pasture and $8004.50 \pm 1314.98 \mathrm{mg} \mathrm{m}^{-2}$ for forest [2]. The Belo Monte mill may produce 1 million tons of $\mathrm{CO}_{2}$ per year during the first ten years [12,39]. Dams such as Jirau and Santo Antônio will have lower emissions, due to the size of the reservoirs [40].

The amount of emissions varies according to the age of the reservoir, the type of land use before impoundment, management practices, climatic conditions [1,2] and/or the location and morphometry of the reservoir [38]. Moreover, it should also be noticed that greenhouse gas emissions in reservoirs are higher in the first 10 years $[39,40]$.

The construction of reservoirs also contribute to the fragmentation of the rivers, relocating or displacing humans (especially of indigenous) [38], changes in water quality [41], interference in migration and spawning fish, flooding and drainage of areas for fish production [42]. Pringle et al. [43] relate some fish-related effects: population fragmentation and isolation, migration interference, increases in exotic lentic-adapted species (non-native fishes) and the threat of extinction of some species. Therefore, dams are fundamental for the maintenance of society; however, one must think about environmental sustainability and socio-economic impacts, i.e., the best way to build, operate and maintain dams [44].

\section{The Potential for New Hydropower Plants in Brazil}

Considering the focus of the hydroelectric expansion in the Amazon, due to the nearly exhausted hydroelectric potential in other Brazilian regions [30], important environmental concerns are raised regarding the hydroelectric potential in the Amazon region and studies reporting the impacts caused by dams in this region, such as the emission of greenhouse gases due to flooding of forest areas, the loss of conservation areas, changes in water quality, interference with the displacement and reproduction of aquatic animals, a decline in biodiversity as well as social and cultural impacts [29,31].

The socio-environmental constraints and vulnerabilities of the use of hydroelectric potential, for each Brazilian region, include flood risks in large areas (Northern region), few perennial rivers (Northeast and South), border rivers, floods and agro-industrial pollution (Southeast) and border rivers with high levels of sedimentation (Midwestern region) [30]. Most of the hydropower plants under construction are located in the state of Mato Grosso and Parana (Table 2). The hydropower reservoir (Sinop) and run-of-river (São Manoel) located in the Amazon basin are scheduled to start operating in 2018 [45]. 
Table 2. Hydroelectric plants: Under construction and planned—data from [23].

\begin{tabular}{cccccc}
\hline & Under Construction & & \multicolumn{3}{c}{ Planned } \\
\hline Plant & $\begin{array}{c}\text { Power Generated } \\
\mathbf{( k W )}\end{array}$ & River/State & Plant & $\begin{array}{c}\text { Power Generated } \\
\mathbf{( k W )}\end{array}$ & River/State \\
\hline Sinop & 400,000 & Teles Pires/MT & Pai Querê & 292,000 & Pelotas/RS e SC \\
Baixo Iguaçu & 350,200 & Iguaçu/PR & Itaocara I & 150,000 & $\begin{array}{c}\text { Paraiba do Sul/RJ } \\
\text { Colíder }\end{array}$ \\
São Roque & 130,000 & Teles Pires/MT & Santa Branca & 62,000 & Tibagi/PR \\
Tibagi Montante & 32,900 & Canoas/SC & São João & 60,000 & Chopim/PR \\
Ponte de Pedra & 30,000 & Tibagi/PR & Itumirim & 50,000 & Corrente/GO \\
& & Ponte de Pedra/MT & Cachoeirinha & 45,000 & Chopim/PR \\
& & Bom Retiro & 35,180 & Taquari/RS \\
\hline
\end{tabular}

\section{Comparison to Other Countries}

Most of the large dams around the world were built between the years of 1950-1989 and are related to population growth and consequently increased energy consumption. Regarding their main use, $39 \%$ were built for power generation, $29 \%$ for irrigation, $14 \%$ for flood control, $8 \%$ for water supply and $10 \%$ for other uses [44]. The reduction in growth rate of number dams built since the 1990s is due to social and environmental concerns, high financial costs and reduction of favorable locations [44]. In Brazil, there was an increase in the deployment of large hydroelectric plants in the 1960s and 1970s due to changes in tax criteria, followed by a reduction in construction of new developments in the 1980s and 1990s due to higher inflation and two oil shocks [46].

The five largest producers of hydroelectricity in the world are: China, Canada, Brazil, the United States and Russia [47]. According to estimates, hydroelectric production may double by 2050, contributing to the reduction of $\mathrm{CO}_{2}$ emissions from fossil fuel plants [1]. When predicting population growth, water, food, energy consumption and dam development from 2010-2050, Chen et al. [44] foresee about 36,813 dams worldwide, with a total reservoir capacity of $9204 \mathrm{~km}^{3}$ in 2050, and, in 2010, there were 32,473 dams with a capacity of $7975 \mathrm{~km}^{3}$. In terms of energy consumption, the estimate is an increase from 134,000 to $183,000 \mathrm{TW}$ h.

Future dams will be concentrated in developing countries and emerging economies (Southeast Asia, South America and Africa). Approximately $75 \%$ of the dams will be of medium and small size (1-100 MW) and $93 \%$ of the future hydroelectric power capacity will be provided by large dams (more than $100 \mathrm{MW}$ ). In Brazil, the dams under construction are concentrated in the North and South regions and those planned are in the South and Southeast regions of the country [38].

\section{Possible Impacts of Climate Change on the Generation of Hydroelectricity}

The increase in greenhouse gas emissions and consequently climate change demonstrates having an impact on energy production in Brazil, as well as in other countries that rely heavily on hydropower [29]. Climate change affects the performance and safety of dams in various ways [14], such as: increased sediment load of rivers, impacting turbine operation and loss of storage; increasing reservoir surface evaporation, reducing the amount of water available; generating changes in rainfall and river flows, interfering with the turbines full capacity operation; and increasing the magnitude of floods that can lead to failures in dams. The main factors that interfere in the generation of hydroelectric power globally [13] are:

- Reduction in average precipitation that implies a reduction in runoff (three to four times).

- Increase in average precipitation. Depending on storage and turbine capacity, increased precipitation can lead to an increase in power generation potential. However, this does not always occur, considering that plants are designed for a certain river flow, and the increase of this flow would only lead to unproductive spills.

- Increase in average temperature. Rising temperatures will affect soil moisture levels, interfering with the runoff and storage of water in dams. In addition, increase of temperature causes changes in atmospheric pressure and wind patterns. These changes can alter the precipitation patterns [30]. 
- Extreme droughts. Depending on the duration of the drought period, the reservoirs act as a buffer, maintaining normal power generation capacity.

- Flooding. It entails sediment loads beyond what is expected, and depending on installed capacity, they do not always bring benefits in terms of increasing the potential for generating power.

There are also the indirect impacts of climate change: water scarcity and competition among other sectors (e.g., agriculture, industries, urban consumption); soil degradation and siltation, depending on the vulnerability of the soil to the action of rainwater and river, scarcity of vegetation and soil desiccation during periods of drought, promoting erosion and transport of sediments to reservoirs [13].

The most cited studies in the literature on the impact of climate change on hydroelectric power production are that of Christensen et al. [48] and Lehner et al. [49]. Lehner et al. [49] analysed the effects of global changes on Europe's hydroelectric potential by applying the WaterGAP model (Water-Global Assessment and Prognosis) [50] for runoff calculations and compared current climate and water use conditions with future scenarios. The study pointed out severe future changes in the discharge regimes that will lead to instability in the European hydroelectric potential that could be reduced by $6 \%$ by the 2070s. Christensen et al. [48] simulated future climatic conditions and their effects on the Colorado River basin. The results of this study indicated warming, reduced precipitation, decreased runoff and a significant reduction in annual hydroelectric power generation: 56\% (2010-2039); 45\% (2040-2069); and 53\% (2070-2098) in relation to the simulated history.

For South America, the projections indicate an increase in temperature and an increase (or decrease) in precipitation up to 2100; for some regions, there are large uncertainties related to precipitation. Warming varies from 1.7 to $6.7^{\circ} \mathrm{C}$ by 2100 and precipitation varies according to the region ( $-22 \%$ in Northeastern Brazil, $+25 \%$ in South-Eastern South America). In Brazil, the Amazon is highlighted as a hotspot of global warming, a region most vulnerable to climate change [3].

In Brazil, few studies have evaluated the impacts of climate change on hydropower reservoirs [21,51]. Some studies have more generally evaluated the impact on river basins, not directly evaluating hydroelectric reservoirs $[52,53]$. Other studies analysed the vulnerability of hydroelectric generation to changes in climate $[30,54]$.

Soito and Freitas [30] reported the risks to energy security in Brazil; the generation of electricity depends significantly on the hydrological availability that can be threatened by increasing water demands (driven by demographic growth and economic development), droughts in the Northeast, and degradation of rivers in the Southeast region (pollution, silting, etc.). In a more recent study, Sorribas et al. [53] examined projections of climate change (2070-2099) and their impacts on discharges from the Amazon basin and identified that, for some regions of the basin, there will be an increase in river discharge (Northwest, annual mean $+9 \%$ ) and, for other regions (central Amazon, annual minimum $-15.9 \%$ ), there will be a possible reduction of flow in dry seasons, which may impact the generation of energy from future hydroelectric plants.

Lucena et al. [21] evaluated the impacts of climate change on Brazilian river basins. The results point out a tendency for reduction in average annual flow in the period 2071-2100, mainly in the Parnaíba (-10.3\%), São Francisco $(-26.4 \%)$ and Tocantins-Araguaia $(-15.8 \%)$ basins (North and Northeast regions of Brazil). In the South and Southeast regions, impacts will not be significant, so, in these regions, reservoir management would mitigate the effects of climate change. According to the results of an investigation by Ribeiro Júnior et al. [51], if climate change scenarios are confirmed, Furnas reservoir levels may decline sharply. The authors proposed a methodology that considers the determination of the length and transgression frequency of level to minimise the conflicts of water use and the impacts on the generation of energy.

Analysis conducted by Nóbrega et al. [55] in the Grand river basin showed an increase in average river flow at the Agua Vermelha reservoir ( $+10 \%$ in the A2 Scenario, from $2508 \mathrm{~m}^{3} \mathrm{~s}^{-1}$ to $2748 \mathrm{~m}^{3} \mathrm{~s}^{-1}$ ). Still, according to the study, the increase of $3{ }^{\circ} \mathrm{C}$ in global mean temperature can result in an increase in average river flow by $24 \%$ (from $2475 \mathrm{~m}^{3} \mathrm{~s}^{-1}$ to $3070 \mathrm{~m}^{3} \mathrm{~s}^{-1}$ ) generating flood risks. However, some projections indicate a reduction in average river flow by up to $20 \%$. 
In assessment of climate change impacts on river basins, there are uncertainties about greenhouse gas (GHG) emission scenarios and global circulation models (GCMs), as well as uncertainties regarding downscaling and hydrological modelling [6]. GCMs produce climate projections, providing information on climate uncertainties and water availability more roughly, and are used directly in forecasting runoff in more general studies [14]. The simulations of climate change impacts are generally carried out with a control period and future scenarios of 30 years, comprising three phases of simulation, namely: model development, control simulation (base period), and simulation of future scenarios [4], in addition to using different variables (Figure 2).

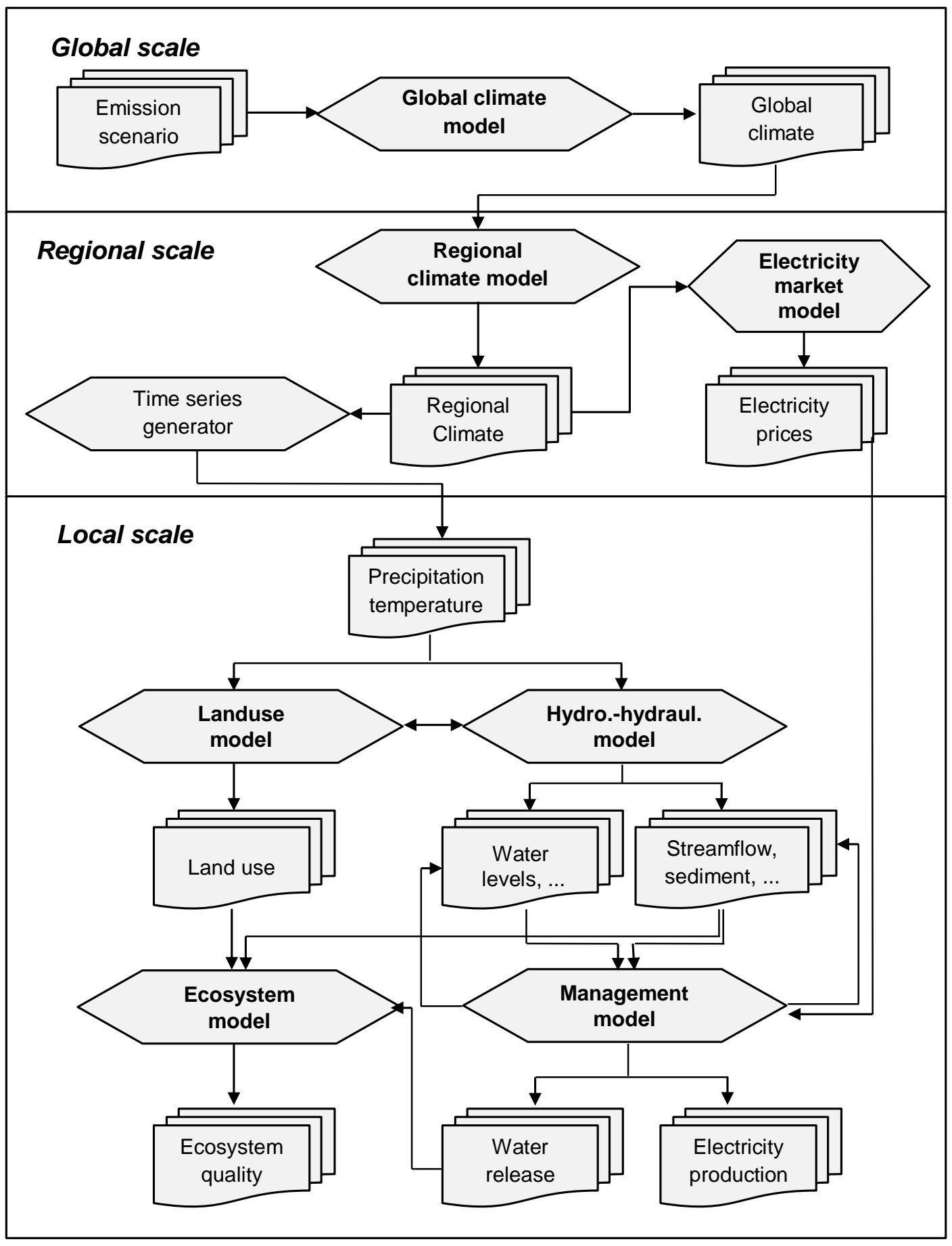

Figure 2. Scheme for simulating the impact of climate change from Schaefli [4]. 
Assessing the impact of climatic changes in impoundment schemes is rather complex $[4,18]$, requiring information such as inter-basin transfers and design specifications. The existing literature generally evaluates single locations, not establishing how to include multiple sites at national or regional levels, due to the need for detailed information on the operational behavior of each site. As reservoirs can serve different uses (e.g., irrigation), the indirect impacts of climate change on hydroelectric dams should also be evaluated [19].

The meteorological variables temperature and precipitation are important in climate change studies for hydroelectric management $[13,16,20,56,57]$. Some authors only model precipitation, considering it the higher impact factor on the availability of water for power generation [21]. Other authors propose a combined study between climatic changes and changes in land use [6,7] or between climate changes and demands for irrigation [5]. The inclusion of sediment load assessment in hydroelectric basins tends to be a significant contribution to the study of hydrological models. Another approach complements the gap: the need for an analysis of water demand, mainly for irrigation.

Some studies adopt only one scenario, not considering the different views of the general circulation models on the evolution of the climate and its repercussion in terms of the river basins, different from the one done by Haguma et al. [6], López-Moreno et al. [7], Gaudard et al. [17] and Parkinson et al. [57]. The use of several scenarios assists in the estimation of different uncertainties involved in hydro-climatic modelling [57], such as parameter uncertainty and model structural uncertainty. Climate models that consider a multi-model set, such as ENSEMBLES or CMIP5, provide more reliable assessment since they include different uncertainties [4].

Table 3 presents some insights on the possible climatic changes and their consequences in the runoff, flow of the rivers and generation of energy in hydroelectric reservoirs. The table includes the methodology used in each study to evaluate how different uncertainties (observational uncertainty, parameter uncertainty and model structural uncertainty) were included. A comparison between Brazil and other countries was also carried out.

In order to assess the impacts of climate change on water resources, it is necessary to predict the runoff of the basin. A model commonly used is the IHACRES, introduced by Jakeman and Hornberger [58], which interfaces climate change input data (temperature and precipitation). The IHACRES is a rainfall-runoff model used to calculate the flow of a river, considering climatic changes.

In some regions, such as in Canada, Manic-5 and Toulnustouc reservoirs, studies indicated positive effects in relation to climate change and power generation. These results are associated with the specific characteristics of the basins; however, as highlighted by the authors, in the long-term, global warming will provide potential negative effects on energy generation [6]. 
Table 3. Methodologies and main results of studies on impacts of climate change on reservoir management.

\begin{tabular}{|c|c|c|c|c|c|c|c|c|}
\hline Study & Local & $\begin{array}{l}\text { Climate Model and Greenhouse } \\
\text { Emission Scenarios (IPCC) }\end{array}$ & Downscaling Method & $\begin{array}{l}\text { Components of the } \\
\text { Model }\end{array}$ & Hydrologic Model & $\begin{array}{l}\text { Simulation and } \\
\text { Optimization } \\
\text { Approach }\end{array}$ & Future Periods & Main Results (Projected Changes) \\
\hline [16] & $\begin{array}{l}\text { Karoon-4 reservoir } \\
\text { (Iran) }\end{array}$ & HADCM3 model ${ }^{\mathrm{a}}(\mathrm{GCM}), \mathrm{A} 2^{\mathrm{b}}$ & Proportional approach & $\begin{array}{l}\text { Temperature and } \\
\text { precipitation }\end{array}$ & $\begin{array}{l}\text { IHACRES } \\
\text { rainfall-runoff } \\
\text { model c }^{\text {[ }}[58]\end{array}$ & $\begin{array}{l}\text { Non-dominated } \\
\text { sorting genetic } \\
\text { algorithm II } \\
\text { (NSGA-II) } \\
\end{array}$ & $\begin{array}{l}2025-2039 \\
2055-2069 \\
2085-2099\end{array}$ & $\begin{array}{l}\text { Temperature: }-1.35,-1.45 \text { and }-2.20{ }^{\circ} \mathrm{C} ; \\
\text { Precipitation: }-18 \%,-0.4 \% \text { and }-30 \% ; \\
\text { Inflow to the Karoon4 reservoir would } \\
\text { decline in the future periods. }\end{array}$ \\
\hline [17] & $\begin{array}{l}\text { Mauvoisin reservoir } \\
\text { and Chanrion } \\
\text { run-of-river power } \\
\text { plant (Switzerland) }\end{array}$ & $\begin{array}{l}10 \text { regional climate models (RCM) } \\
\text { Ensembles project } \\
\text { (ensembles-eu.metoffice.com), A1B }\end{array}$ & Delta method & $\begin{array}{c}\text { Temperature, } \\
\text { scenarios of energy } \\
\text { consumption and } \\
\text { prices }\end{array}$ & $\begin{array}{l}\text { Glacier Evolution } \\
\text { Runoff Model } \\
\text { (GERM) }[59,60]\end{array}$ & $\begin{array}{l}\text { Threshold } \\
\text { Accepting }\end{array}$ & 2011-2100 & $\begin{array}{c}\text { Inflows are expected to decrease at average } \\
\text { by } 18 \% \text { from 2001-2010 to } 2091-2100 ; \\
\text { Power generation: }-20 \% ; \\
\text { Power generation after optimization: }-16 \% .\end{array}$ \\
\hline [20] & $\begin{array}{c}\text { Khersan 1, Karoon } 3 \\
\text { and Karoon } 4 \text { reservoirs } \\
\text { (Iran) }\end{array}$ & HADCM3 model (GCM), A2 & Proportional approach & $\begin{array}{l}\text { Temperature and } \\
\text { precipitation }\end{array}$ & IHACRES model & $\begin{array}{l}\text { Systems dynamics } \\
\text { (SD)/Nonlinear } \\
\text { programming } \\
\text { (NLP) }\end{array}$ & $\begin{array}{l}2025-2039 \\
2055-2069 \\
2085-2099\end{array}$ & $\begin{array}{c}\text { Temperature increase; } \\
\text { Decrease of precipitation and inflow; } \\
\text { Power generation (simulation } \\
\text { multi-reservoir after optimization): }-23 \% \text {, } \\
-7 \% \text { and }-34 \% \text {. }\end{array}$ \\
\hline [57] & $\begin{array}{l}\text { Reservoirs and } \\
\text { run-of-river schems } \\
\text { (Canada) }\end{array}$ & $\begin{array}{l}8 \mathrm{GCM} \text { with } 23 \text { downscaled } \\
\text { climate projections, A1B, A2 e B1 }\end{array}$ & $\begin{array}{l}\text { Downscaled climate } \\
\text { projections of Pacific } \\
\text { Climate Impacts } \\
\text { Consortium (PCIC) }\end{array}$ & $\begin{array}{l}\text { Temperature and } \\
\text { precipitation }\end{array}$ & $\begin{array}{l}\text { Variable Infiltration } \\
\text { Capacity (VIC) } \\
\text { model [61] }\end{array}$ & $\begin{array}{c}\text { Robust } \\
\text { optimization }\end{array}$ & 2050 & $\begin{array}{l}\text { Temperature increase; Increased } \\
\text { precipitation trend in most seasons and } \\
\text { annually; More runoff available in the } \\
\text { winter and spring seasons, and with drier } \\
\text { conditions in the summer; Hydropower } \\
\text { potential: }+11 \% \text {. }\end{array}$ \\
\hline [6] & $\begin{array}{l}\text { Reservoirs (Manic-5 } \\
\text { and Toulnustouc) and } \\
\text { run-of-river } \\
\text { hydropower plant } \\
\text { (Manic-1, Manic-2 and } \\
\text { Manic-3) (Canada) } \\
\end{array}$ & $\begin{array}{l}\text { Climate model ensemble } \\
\text { (13 GCM) } \\
\text { A1B, A2 and B1 }\end{array}$ & $\begin{array}{l}\text { Downscaling method } \\
\text { proposed by } \\
\text { Widmann et al. [62]. }\end{array}$ & $\begin{array}{l}\text { Temperature, } \\
\text { precipitation, relative } \\
\text { humidity, solar } \\
\text { radiation, wind speed, } \\
\text { topography and soil } \\
\text { types and land uses } \\
\end{array}$ & $\begin{array}{l}\text { Soil and Water } \\
\text { Assessment Tool } \\
\quad \text { (SWAT) }\end{array}$ & $\begin{array}{l}\text { Sampling } \\
\text { Stochastic } \\
\text { Dynamic } \\
\text { Programming } \\
\text { (SSDP) }\end{array}$ & $\begin{array}{l}2010-2039 \\
2040-2069 \\
2070-2099\end{array}$ & $\begin{array}{c}\text { Temperature }(2070-2099):+3 \text { to }+10{ }^{\circ} \mathrm{C} ; \\
\text { Precipitation in the winter }(2070-2099):+5 \\
\text { to }+60 \% \text {; Annual inflow volume: }+4.3 \% \text {, } \\
+9.1 \% \text { and }+13.5 \% \text {; Average annual power } \\
\text { generation: }+4.2 \%,+8.7 \% \text { and }+14.1 \%) ; \\
\text { Unproductive Spills increase. }\end{array}$ \\
\hline [7] & Yesa reservoir (Spain) & $\begin{array}{l}\text { Climate model ensemble (12 } \\
\text { RCM), A1B }\end{array}$ & Delta method & $\begin{array}{l}\text { Temperature, } \\
\text { precipitation, } \\
\text { reservoir inflows and } \\
\text { outflows, storage } \\
\text { level, soil types and } \\
\text { land cover }\end{array}$ & $\begin{array}{l}\text { Hydro-Ecologic } \\
\text { Simulation System } \\
\text { (RHESSys) }\end{array}$ & - & 2021-2050 & $\begin{array}{l}\text { Temperature: }+1 \text { to }+2{ }^{\circ} \mathrm{C} \text {; Annual average } \\
\text { rainfall: }-10 \% \text {; Annual streamflow: }-13.8 \% \text {; } \\
\text { Annual runoff (considering evolution of } \\
\text { land cover): }-16 \% \text {; Annual runoff } \\
\text { (combined effects of climate and land cover } \\
\text { change): }-29.8 \% \text {. }\end{array}$ \\
\hline [5] & $\begin{array}{l}\text { Major existing and } \\
\text { planned new } \\
\text { hydropower plants } \\
\text { (reservoir and } \\
\text { run-of-river) of } \\
\text { Zambezi river basin } \\
\text { (Southern Africa) }\end{array}$ & $\begin{array}{l}2 \text { GCM (CNRM-CM3 and } \\
\text { ECHAM5 MPI-M) }{ }^{d}, A 2\end{array}$ & $\begin{array}{l}\text { Direct use of regional } \\
\text { models }\end{array}$ & $\begin{array}{l}\text { Temperature, } \\
\text { precipitation and } \\
\text { irrigation } \\
\text { development }\end{array}$ & $\begin{array}{l}\text { Water Evaluation } \\
\text { and Planning } \\
\text { (WEAP) [63-65] }\end{array}$ & - & 2050-2070 & $\begin{array}{l}\text { Higher average temperatures; Potentially } \\
\text { reducing average electricity generation (12\% } \\
\text { in the Kariba reservoir); Reduction in the } \\
\text { average annual generation in usual } \\
\text { irrigation growth (6\%); Reduction in the } \\
\text { average anual generation when irrigation is } \\
\text { prioritized ( } 20 \% \text { in Cahora Bassa) }\end{array}$ \\
\hline [66] & $\begin{array}{l}\text { Tekeze reservoir } \\
\text { (Ethiopia) }\end{array}$ & $\begin{array}{l}\text { CORDEX-Africa (RCM), RCP4.5 } \\
\text { and RCP8.5 climate scenarios }\end{array}$ & - & $\begin{array}{l}\text { Temperature, } \\
\text { precipitation, } \\
\text { topography and soil } \\
\text { types and land uses }\end{array}$ & $\begin{array}{l}\text { Soil and Water } \\
\text { Assessment Tool } \\
\text { (SWAT) }\end{array}$ & $\begin{array}{l}\text { HEC-ResPRM } \\
\text { Optimization } \\
\text { Model }^{\mathrm{f}}\end{array}$ & $\begin{array}{l}2011-2040 \\
2041-2070 \\
2071-2100\end{array}$ & $\begin{array}{l}\text { Mean annual temperature: }+1.1^{\circ} \mathrm{C} \text { and } \\
+3.38^{\circ} \mathrm{C} \text { under RCP4.5 and RCP8.5 } \\
\text { scenarios; Mean annual precipitation: }+45 \% \text {; } \\
\text { Results showed increase in annual and } \\
\text { monthly inflow into the reservorir except in } \\
\text { dry months from May to June. }\end{array}$ \\
\hline
\end{tabular}


Table 3. Cont.

\begin{tabular}{|c|c|c|c|c|c|c|c|c|}
\hline Study & Local & $\begin{array}{l}\text { Climate Model and Greenhouse } \\
\text { Emission Scenarios (IPCC) }\end{array}$ & Downscaling Method & $\begin{array}{l}\text { Components of the } \\
\text { Model }\end{array}$ & Hydrologic Model & $\begin{array}{l}\text { Simulation and } \\
\text { Optimization } \\
\text { Approach }\end{array}$ & Future Periods & Main Results (Projected Changes) \\
\hline [21] & Reservoirs (Brazil) & HADCM3 model (GCM), A2 e B2 & $\begin{array}{l}\text { PRECIS (Providing } \\
\text { Regional Climates for } \\
\text { Impacts Studies) model } \\
\text { (Hadley Centre, UK) }\end{array}$ & Precipitation & $\begin{array}{l}\text { Linear rainfall-flow } \\
\text { model for } \\
\text { elasticities }\end{array}$ & SUISHI-O $\mathrm{g}$ & 2071-2100 & $\begin{array}{l}\text { Firm power (A2 and B2 emission scenarios, } \\
\text { respectively): }-1.58 \% \text { and }-3.15 \% \text {; General } \\
\text { negative trend in flow with varying } \\
\text { seasonal impacts; São Francisco basin } \\
\text { seemed to be the most affected (decrease in } \\
\text { energy production would reach more than } \\
7 \% \text { in the B2 scenario). }\end{array}$ \\
\hline [51] & $\begin{array}{l}\text { Furnas reservoir } \\
\text { (Brazil) }\end{array}$ & HADCM3 model (GCM), A1B & $\begin{array}{c}\text { Regional ETA model } \\
\text { (National Institute for } \\
\text { Space Research-INPE, } \\
\text { Brazil) }\end{array}$ & $\begin{array}{l}\text { Temperature, } \\
\text { precipitation, relative } \\
\text { humidity, solar } \\
\text { radiation, wind speed, } \\
\text { topography and soil } \\
\text { types and land uses }\end{array}$ & $\begin{array}{l}\text { MGB-IPH model } \\
\text { [67] }\end{array}$ & $\begin{array}{l}\text { Frequency and } \\
\text { duration model }\end{array}$ & $\begin{array}{l}2011-2040 \\
2041-2070 \\
2071-2099\end{array}$ & $\begin{array}{l}\text { Increased trend of rain rates, not reflecting } \\
\text { on flow; Period 2041-2070: prolonged } \\
\text { drought, the reservoir can be emptied } \\
\text { completely so that the energy demand is } \\
\text { met; Increase in generation by } 32 \% \text { while } \\
\text { maintaining the fullest reservoir. }\end{array}$ \\
\hline
\end{tabular}

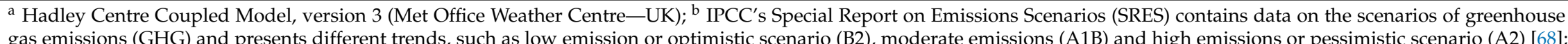
${ }^{c}$ IHACRES model-Identification of unit Hydrographs and Component flows from Rainfall, Evaporation and Streamflow data; ${ }^{\mathrm{d}}$ Drawn from the European Union (EU) WATCH3 dataset of statistically downscaled climate models; ${ }^{\mathrm{e}}$ IPCC's Fifth Assessment Report-CMIP5: established new scenarios of climate change: high emission scenario (RCP 8.5), medium stabilization scenarios (RCP 4.5 and RCP 6.0) and mitigation scenario (RCP 2.6) [69]; ${ }^{\mathrm{f}}$ HEC-ResPRM-US Army Corps of Engineer's Reservoir Evaluation System Perspective Reservoir Model; g SUISHI-O-Modelo de Simulação a Usinas Individualizadas de Subsistemas Hidrotérmicos Interligados developed by CEPEL-Centro de Pesquisas de Energia Elétrica (Electric

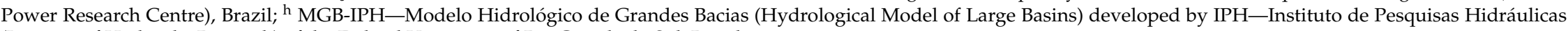
(Institute of Hydraulic Research) of the Federal University of Rio Grande do Sul, Brazil. 


\section{Adaptations to Reduce Vulnerability and Increase Resilience}

Soito and Freitas [30] suggested that, in addition to the management of Brazilian reservoirs in terms of optimisation and adaptation to climate change, other measures should be taken into account for planning, execution and control phases of the plants, namely: establishment of an orderly use of the soil in the drainage basin; conservation of vegetation growth; regulation of the rivers flow and their tributaries; and the controlled disposal of industrial waste. It should also be considered the monitoring of sediment transport [70]. An overview of different adaptation strategies to reduce vulnerability of hydroelectric reservoirs to climate change is given in Table 4.

Table 4. Adaptations to reduce vulnerability of hydroelectric reservoirs to climate change.

\begin{tabular}{ll}
\hline Study & Adaptations to Reduce Vulnerability of Hydroelectric Reservoirs to Climate Change \\
\hline & $\begin{array}{l}\text { Obtaining information on the climatic impacts (monitoring of the climate and the runoff of the basins) } \\
\text { in the hydroelectric generation and incorporating climatic risks in its management; } \\
\text { Investments in adequate infrastructure, with equipment designed to operate in different climate } \\
\text { conditions (e.g., turbine types); } \\
\text { Modernization of plants to enable long-term sustainability; } \\
\text { Development of drought management plans to deal with water competition; } \\
\text { Modifications to operating rules; } \\
\text { Management of land use to reduce soil erosion in the basin and reservoir; } \\
\text { Consideration of the diversification of the energy matrix. }\end{array}$ \\
\hline [22] & $\begin{array}{l}\text { Dynamic management with water allocation adjustments. } \\
\text { [30] }\end{array}$ \\
$\begin{array}{l}\text { Controlled disposal of industrial waste; } \\
\text { The conservation of vegetation growth; }\end{array}$ \\
\hline Regulation of flows of rivers and their tributaries. \\
\hline Adaptations between hydroelectric and alternative scenarios involving other sources of energy.
\end{tabular}

The adaptability of hydroelectric schemes to climate change is dependent on local characteristics, specifically: project specifications; storage volume; morphological regime and environmental legislation [4,18]. For example:

- Reservoirs with smaller surface area and greater depth tend to be less affected by global warming, which increases evaporation rate of reservoir (according to previous study, $1.1 \mathrm{~m}$ depth on average per year) [13].

- Some hydropower systems offer flexibility of water storage, pump-storage HPP. In periods of lower demands, the water is rebounded to a reservoir with higher elevation, and, in periods of higher demand, the water is released by the turbines. In this case, the generation of hydroelectricity is less dependent on changes in the hydrological regime [4]. The limitations for the construction of these hydroelectric schemes in Brazil are related to the establishment of regulatory bases and economic viability.

- Optimised operating rules can balance power generation $[7,16,17,20,57]$. An example of such operational policies would be raising and lowering reservoir level during some seasons. Haguma et al. [6] proposed as adaptive operational policies for Manicouagan Reservoir (Canada) 
the lowering in reservoir water level during winter and raising during spring. For the Furnas HPP reservoir (Brazil), Ribeiro Júnior et al. [51] proposed an operative rule that contemplates the time and the cycle of attendance to a certain level of the reservoir, to attend to the generation of energy and to guarantee the sustainability of multiple uses of water for the future climate.

Analyses indicate that hydroelectric managers usually consider historical hydro-meteorological data in the planning and design of new hydropower stations, but data should be also included on the possible impacts of climate change [14]. In Brazil, this new strategy is also necessary. With the inclusion of climate change impacts in planning, even if there are changes in flows, the plant can act in a balanced way, reducing losses in energy generation.

According to Lumbroso et al. [14], this strategic management leads to a set of possible options for hydroelectric schemes and impacts the amount of energy generated and future economic return. In Brazil, there is a need for climate and hydrological forecasting to anticipate hydrological risks and to assess the impacts and vulnerability of hydroelectric plants considering changes in climate and adaptation measures [30,51]. However, the influence of the actions taken is greater during the hydroelectric planning and design phases [14].

The diversification of the energy mix is considered a form of adaptation [13]. Thus, in Brazil, different sources of renewable energy can be managed in parallel:

- Encouraging the use of solar and wind energy can contribute to the reduction of greenhouse gases and to Brazilian social and economic development [28]. Biomass as an energy source is also interesting due to the amount of waste from agriculture and forest products industries, extracted mainly from the sugar and alcohol industry [11,12].

- Sources such as biomass (from bagasse and sugar cane straw) and wind power can contribute significantly to the generation of energy in periods with lower rainfall intensity, as it coincides with the more intense potential of these sources [8]. It can complement the generation of hydroelectricity in the period of greater fragility, especially the run-of-river hydropower plants.

- The great annual variability in the hydrological conditions and the intense rain seasonality can put at risk the Brazilian hydrothermal energy generation system. However, a complementarity between hydroelectric, wind and solar photovoltaic systems could contribute to the stability of production and a decrease in thermoelectric generation [71].

\section{Discussion}

The assessment of projections of climate change allows better understanding of the magnitude of water and energy risks as well as the adoption of adaptation measures to meet future energy demands. The vulnerability and resilience of each hydroelectric plant depends on specific characteristics such as the type of plant (reservoir, pumped-storage or run-of-river), operating strategies, turbine resistance to sediments and the vulnerability of the hydrological regime.

Studies of the impact of climate change on the hydrological regime anticipated possible future developments, but interpretation should cover modelling uncertainties, especially related to climate change scenarios. These studies provided an overview of the trends and enable the establishment of hydroelectric reservoir management strategies. The impacts on the availability of water to the reservoirs can be predicted, which facilitates the designation of a plant operation strategy in order to mitigate the effects throughout the year or the adoption of other measures to guarantee demand to be met.

When establishing adaptive strategies, it is also necessary to investigate the impacts of adaptive actions on ecological integrity of rivers downstream of the reservoir, and there should be concerns related to maintenance of environmental flows, as highlighted in Spalding-Fecher et al. [5].

The analyses of the temperature and precipitation variables are fundamental in projections of climatic changes and in the evaluation of impacts on the generation of energy by hydroelectric plants. Precipitation directly influences the refilling of aquifers and river flow, i.e., the availability of 
water resources. Temperature influences the evaporation of the reservoir and the evapotranspiration of the vegetation-also impacting the availability of water in the reservoir. Variations in temperature also impact the behavior of other climatic variables (wind speed, humidity, precipitation). Investigations also highlighted the need for joint evaluation of temperature and precipitation, since evapotranspiration and evaporation may counterbalance precipitation $[5,6,30]$. That is, even if there is an increase in rainfall in some regions, higher temperature would increase the rates of evaporation of the reservoir and evapotranspiration in the basin, generating loss of water to the atmosphere. Other variables that can complement the analysis: demand for irrigation and land use-related to the silting of river banks and changes in evapotranspiration rates.

In Brazil, climate change trends indicate that the regions that will suffer the most changes will be the Amazon and the Northeast. Considering the Amazon, strategies should be implemented, due to the clear tendency, for the region, of construction of run-of-river plants, the kind of power plant in which the impacts of global warming are most significant. Considering the Northeast, in strategic terms, the country can opt for complementarity with the development of other renewable sources of energy, such as wind and solar, given its enormous potential for generation, as evaluated in the study of Jong et al. [12].

Based on the study of several articles dealing with the impact of climate change on the management of hydropower reservoirs and other related articles, a framework was elaborated (Figure 3).

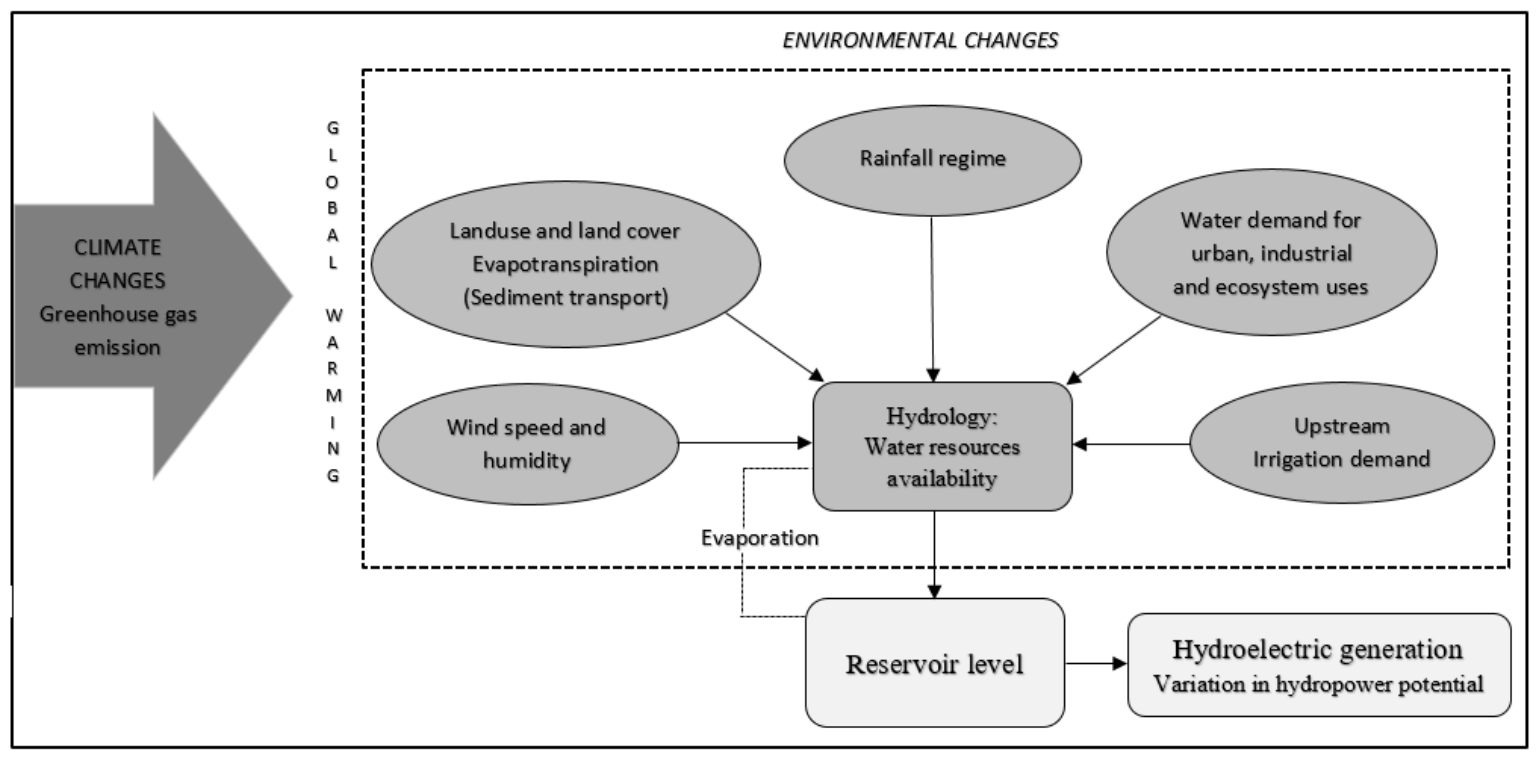

Figure 3. Framework-Climate change and reservoir management.

This research provides several conclusions related to climate and environmental changes in the context of hydropower reservoirs, which are useful for the academic and industry communities. A summary of the relationship between different variables is presented (see also Figure 3):

- Global climate change affects power generation in hydropower reservoirs;

- The increase in temperature causes changes in atmospheric pressure and wind patterns and consequently in precipitation and humidity patterns;

- The combination of changes in precipitation and temperature affect the moisture levels of soil;

- Increase of temperatures results in an increase in potential evaporation;

- Changes in wind speed and humidity may compensate for or amplify the increase in temperature, which may interfere with the evaporation rate of the basin and reservoirs;

- Precipitation is the climatic variable that most affects the flow of rivers; 
- Increased precipitation can lead to a rise in river flow; however, the increase in temperature may counterbalance the effect of this rise, as it increases the rate of evaporation of the reservoirs and the evapotranspiration in the basin;

- Global warming increases the demand for water for agricultural exploitation (mainly irrigation) and other socio-environmental demands;

- Changes in land cover alters the rate of evapotranspiration, which may imply changes in runoff characteristics;

- Some changes in land cover can lead to soil degradation (silting), which can affect both the basin and the reservoir level due to sediment transport-aggravating the negative impacts of climate change;

- Hydrological impacts vary according to: precipitation intensity, basin characteristics, type of vegetation and/or changes in land cover;

- As a chain effect, changes in runoff can affect the production of electricity.

\section{Conclusions}

In summary, climatic and environmental variables impact the volume of water available for the generation of energy in hydropower reservoirs, hence the need for combined studies (considering these different variables) to develop reliable scenarios for the future availability of water resources for hydroelectric power generation and for the establishment of rules for flexible reservoir operation.

Author Contributions: Viviane de Souza Dias, Marta Pereira da Luz and Gabriela M. Medero performed the studies and wrote the paper. Diego Tarley Ferreira Nascimento has developed the maps and assisted in the paper preparation.

Acknowledgments: The work was supported by the National Council of Scientific and Technological Development (CNPq) through the program Science without Borders, and National Agency of Electric Power (ANEEL) - Project and Development code 0394-1014-2010, through Eletrobras Furnas Company, both from Brazil's government. The authors are also grateful to Coordination for the Improvement of Higher Education Personnel (CAPES) for the granting of the master's degree grant that maintained the first author.

Conflicts of Interest: The authors declare no conflict of interest.

\section{References}

1. IEA. International Energy Agency. Technology Roadmap: Hydropower. Available online: http:/ /www.iea.org/ publications/freepublications/publication/2012_Hydropower_Roadmap.pdf (accessed on 21 April 2016).

2. Lessa, A.C.; dos Santos, M.A.; Maddock, J.E.; dos Santos Bezerra, C. Emissions of greenhouse gases in terrestrial areas pre-existing to hydroelectric plant reservoirs in the Amazon: The case of Belo Monte hydroelectric plant. Renew. Sustain. Energy Rev. 2015, 51, 1728-1736. [CrossRef]

3. IPCC. Intergovernmental Panel on Climate Change. Climate Change 2014: Impacts, Adaptation and Vulnerability—Fifth Assessment Report-Part B: Regional Aspects. Available online: http:/ /www.ipcc.ch/ pdf/assessment-report/ar5/wg2/WGIIAR5-Chap27_FINAL.pdf (accessed on 17 June 2016).

4. Schaefli, B. Projecting hydropower production under future climates: A guide for decision-makers and modelers to interpret and design climate change impact assessments. Wiley Interdiscip. Rev. Water 2015, 2, 271-289. [CrossRef]

5. Spalding-Fecher, R.; Chapman, A.; Yamba, F.; Walimwipi, H.; Kling, H.; Tembo, B.; Nyambe, I.; Cuamba, B. The vulnerability of hydropower production in the Zambezi River Basin to the impacts of climate change and irrigation development. Mitig. Adapt. Strateg. Glob. Chang. 2014, 19, 1-22. [CrossRef]

6. Haguma, D.; Leconte, R.; Côté, P.; Krau, S.; Brissette, F. Optimal hydropower generation under climate change conditions for a Northern water resources system. Water Resour. Manag. 2014, 28, 4631-4644. [CrossRef]

7. López-Moreno, J.I.; Zabalza, J.; Vicente-Serrano, S.M.; Revuelto, J.; Gilaberte, M.; Azorin-Molina, C.; Moran-Tejeda, E.; Garcia-Ruiz, J.M.; Tague, C. Impact of climate and land use change on water availability and reservoir management: Scenarios in the Upper Aragon River, Spanish Pyrenees. Sci. Total Environ. 2014, 493, 1222-1231. [CrossRef] [PubMed] 
8. Da Silva, R.C.; De Marchi Neto, I.; Seifert, S.S. Electricity supply security and the future role of renewable energy sources in Brazil. Renew. Sustain. Energy Rev. 2016, 59, 328-341. [CrossRef]

9. EPE. Empresa de Pesquisa Energética (Brasil) Balanço Energético Nacional 2017: Ano Base 2016/Empresa de Pesquisa Energética; EPE: Rio de Janeiro, Brazil, 2017. Available online: https:/ / ben.epe.gov.br/downloads/Relatorio_ Final_BEN_2017.pdf (accessed on 5 March 2018). (In Portuguese)

10. ANEEL. Agência Nacional de Energia Elétrica. Matriz de Energia Elétrica, 2018. Available online: http://www2.aneel.gov.br/aplicacoes/capacidadebrasil/OperacaoCapacidadeBrasil.cfm (accessed on 5 March 2018). (In Portuguese)

11. Pottmaier, D.; Melo, C.R.; Sartor, M.N.; Kuester, S.; Amadio, T.M.; Fernandes, C.A.H.; Marinha, D.; Alarcon, O.E. The Brazilian energy matrix: From a materials science and engineering perspective. Renew. Sustain. Energy Rev. 2013, 19, 678-691. [CrossRef]

12. De Jong, P.; Kiperstok, A.; Torres, E.A. Economic and environmental analysis of electricity generation technologies in Brazil. Renew. Sustain. Energy Rev. 2015, 52, 725-739. [CrossRef]

13. Mukheibir, P. Potential consequences of projected climate change impacts on hydroelectricity generation. Clim. Chang. 2013, 121, 67-78. [CrossRef]

14. Lumbroso, D.M.; Woolhouse, G.; Jones, L. A review of the consideration of climate change in the planning of hydropower schemes in sub-Saharan Africa. Clim. Chang. 2015, 133, 621-633. [CrossRef]

15. Schaeffer, R.; Szklo, A.S.; de Lucena, A.F.P.; Borba, B.S.M.C.; Nogueira, L.P.P.; Fleming, F.P.; Troccoli, A.; Harrison, M.; Boulahya, M.S. Energy sector vulnerability to climate change: A review. Energy 2012, 38, 1-12. [CrossRef]

16. Ahmadi, M.; Haddad, O.B.; Loáiciga, H.A. Adaptive reservoir operation rules under climatic change. Water Resour. Manag. 2015, 29, 1247-1266. [CrossRef]

17. Gaudard, L.; Gilli, M.; Romerio, F. Climate change impacts on hydropower management. Water Resour. Manag. 2013, 27, 5143-5156. [CrossRef]

18. Sample, J.E.; Duncan, N.; Ferguson, M.; Cooksley, S. Scotland's hydropower: Current capacity, future potential and the possible impacts of climate change. Renew. Sustain. Energy Rev. 2015, 52, 111-122. [CrossRef]

19. Gaudard, L.; Romerio, F.; Dalla Valle, F.; Gorret, R.; Maran, S.; Ravazzani, G.; Stoffel, M.; Volonterio, M. Climate change impacts on hydropower in the Swiss and Italian Alps. Sci. Total Environ. 2014, 493, 1211-1221. [CrossRef] [PubMed]

20. Jahandideh-Tehrani, M.; Haddad, O.B.; Loáiciga, H.A. Hydropower reservoir management under climate change: The karoon reservoir system. Water Resour. Manag. 2014, 29, 749-770. [CrossRef]

21. De Lucena, A.F.P.; Szklo, A.S.; Schaeffer, R.; de Souza, R.R.; Borba, B.S.M.C.; da Costa, I.V.L.; Pereira Júnior, A.O.P.; da Cunha, S.H.F. The vulnerability of renewable energy to climate change in Brazil. Energy Policy 2009, 37, 879-889. [CrossRef]

22. Ward, M.N.; Brown, C.M.; Baroang, K.M.; Kaheil, Y.H. Reservoir performance and dynamic management under plausible assumptions of future climate over seasons to decades. Clim. Chang. 2013, 118, 307-320. [CrossRef]

23. ANEEL. Agência Nacional de Energia Elétrica. Banco de Informações de Geração, 2018. Available online: http:/ / www2.aneel.gov.br/aplicacoes/capacidadebrasil/capacidadebrasil.cfm (accessed on 5 March 2018). (In Portuguese)

24. MME. Ministério de Minas e Energia. Energia Hidráulica em 2014 no Brasil e Mundo. Available online: http:/ / www.mme.gov.br/documents/1138769/2252804/Energia+Hidr\%C3\%A1ulica+em+2014. pdf/a4f31f91-1737-4f3b-85fb-f960706d0c56 (accessed on 8 May 2016). (In Portuguese)

25. Ferreira, J.H.I.; Camacho, J.R.; Malagoli, J.A.; Guimarães Júnior, S.C. Assessment of the potential of small hydropower development in Brazil. Renew. Sustain. Energy Rev. 2016, 56, 380-387. [CrossRef]

26. Hunt, J.D.; Freitas, M.A.V.; Pereira Junior, A.O. Enhanced-Pumped-Storage: Combining pumped-storage in a yearly storage cycle with dams in cascade in Brazil. Energy 2014, 78, 513-523. [CrossRef]

27. SIGEL/ANEEL. Sistema de Informações Geográficas do Setor Elétrico, 2016. Available online: http: / / sigel. aneel.gov.br/portal/home/index.html (accessed on 6 August 2016). (In Portuguese)

28. Ribeiro, A.E.D.; Arouca, M.C.; Coelho, D.M. Electric energy generation from small-scale solar and wind power in Brazil: The influence of location, area and shape. Renew. Energy 2016, 85, 554-563. [CrossRef] 
29. Prado Júnior, F.A.; Athayde, S.; Mossa, J.; Bohlman, S.; Leite, F.; Oliver-Smith, A. How much is enough? An integrated examination of energy security, economic growth and climate change related to hydropower expansion in Brazil. Renew. Sustain. Energy Rev. 2016, 53, 1132-1136. [CrossRef]

30. Soito, J.L.D.S.; Freitas, M.A.V. Amazon and the expansion of hydropower in Brazil: Vulnerability, impacts and possibilities for adaptation to global climate change. Renew. Sustain. Energy Rev. 2011, 15, 3165-3177. [CrossRef]

31. Westin, F.F.; Dos Santos, M.A.; Martins, I.D. Hydropower expansion and analysis of the use of strategic and integrated environmental assessment tools in Brazil. Renew. Sustain. Energy Rev. 2014, 37, 750-761. [CrossRef]

32. Ansar, A.; Flyvbjerg, B.; Budzier, A.; Lunn, D. Should we build more large dams? The actual costs of hydropower megaproject development. Energy Policy 2014, 69, 43-56. [CrossRef]

33. Fearnside, P.M. Greenhouse-gas emissions from Amazonian hydroelectric reservoirs: The example of Brazil's Tucurui Dam as compared to fossil fuel alternatives. Environ. Conserv. 1997, 24, 64-75. [CrossRef]

34. Rosa, L.P.; Schaeffer, R. Global warming potentials. The case of emissions from dams. Energy Policy 1995, 23, 149-158. [CrossRef]

35. Gagnon, L.; van de Vate, J.F. Greenhouse gas emissions from hydropower. Energy Policy 1997, $25,7-13$. [CrossRef]

36. Rosa, L.P.; Schaeffer, R.; Santos, M.A. Are hydroelectric dams in the Brazilian Amazon significant sources of greenhouse gases? Environ. Conserv. 1996, 23, 2-6. [CrossRef]

37. Giles, J. Methane quashes green credentials of hydropower. Nature 2006, 524-525. [CrossRef] [PubMed]

38. Zarfl, C.; Lumsdon, A.E.; Berlekamp, J.; Tydecks, L.; Tockner, K. A global boom in hydropower dam construction. Aquat. Sci. 2015, 77, 161-170. [CrossRef]

39. Alves, L.A.; Uturbey, W. Environmental degradation costs in electricity generation: The case of the Brazilian electrical matrix. Energy Policy 2010, 38, 6204-6214. [CrossRef]

40. Fearnside, P.M. Tropical hydropower in the clean development mechanism: Brazil's Santo Antônio Dam as an example of the need for change. Clim. Chang. 2015, 131, 575-589. [CrossRef]

41. Melikoglu, M. Hydropower in Turkey: Analysis in the view of Vision 2023. Renew. Sustain. Energy Rev. 2013, 25, 503-510. [CrossRef]

42. Poff, N.L.R.; Olden, J.D. Can dams be designed for sustainability? Science 2017, 358, 1252-1253. [CrossRef] [PubMed]

43. Pringle, C.M.; Freeman, M.C.; Freeman, B.J. Regional effects of hydrologic alterations on riverine macrobiota in the new world: Tropical-Temperate comparisons. Bioscience 2000, 50, 807-823. [CrossRef]

44. Chen, J.; Shi, H.; Sivakumar, B.; Peart, M.R. Population, water, food, energy and dams. Renew. Sustain. Energy Rev. 2016, 56, 18-28. [CrossRef]

45. ONS. Operador Nacional do Sistema Elétrico. Diagrama Esquemático das Usinas Hidrelétricas do SIN, 2015. Available online: http:/ /www.ons.org.br/sites/multimidia/DocumentosCompartilhados/dados/ \%0ADADOS2014_ONS/2_4.html\%0A (accessed on 5 March 2018). (In Portuguese)

46. Mello, F.M. A História das Barragens no Brasil, Séculos XIX, XX e XXI: Cinquenta anos do Comitê Brasileiro de Barragens; CBDB: Rio de Janeiro, Brazil, 2011; Available online: http:/ / www.cbdb.org.br/documentos/a_ historia_das_barragens_no_brasil.pd (accessed on 17 August 2016). (In Portuguese)

47. IEA. International Energy Agency. Key World Energy Statistics, 2017. Available online: https://www.iea. org/publications / freepublications / publication/KeyWorld2017.pdf (accessed on 5 March 2018).

48. Christensen, N.S.; Wood, A.W.; Voisin, N.; Lettenmaier, D.P.; Palmer, R.N. The effects of climate change on the hydrology and water resources of the Colorado River basin. Clim. Chang. 2004, 62, 337-363. [CrossRef]

49. Lehner, B.; Czisch, G.; Vassolo, S. The impact of global change on the hydropower potential of Europe: A model-based analysis. Energy Policy 2005, 33, 839-855. [CrossRef]

50. Alcamo, J.; Döll, P.; Henrichs, T.; Kaspar, F.; Lehner, B.; Rösch, T.; Siebert, S. Development and testing of the WaterGAP 2 global model of water use and availability. Hydrol. Sci. J. 2003, 48, 317-337. [CrossRef]

51. Ribeiro Junior, L.U.; Zuffo, A.C.; Silva, B.C. Development of a tool for hydroeletric reservoir operation with multiple uses considering effects of climate changes. Case study of Furnas HPP. Rev. Bras. Recur. Hidricos 2016, 21, 300-313. [CrossRef] 
52. Braga, A.C.; da Silva, R.M.; Santos, C.A.; de Oliveira Galvão, C.; Nobre, P. Downscaling of a global climate model for estimation of runoff, sediment yield and dam storage: A case study of Pirapama basin, Brazil. J. Hydrol. 2013, 498, 46-58. [CrossRef]

53. Sorribas, M.V.; Paiva, R.C.D.; Melack, J.M.; Bravo, J.M.; Jones, C.; Carvalho, L.; Beighley, E.; Forsberg, B.; Costa, M.H. Projections of climate change effects on discharge and inundation in the Amazon basin. Clim. Chang. 2016, 136, 555-570. [CrossRef]

54. Andrade, E.M.; Paulo Cosenza, J.; Pinguelli Rosa, L.; Lacerda, G. The vulnerability of hydroelectric generation in the Northeast of Brazil: The environmental and business risks for CHESF. Renew. Sustain. Energy Rev. 2012, 16, 5760-5769. [CrossRef]

55. Nóbrega, M.T.; Collischonn, W.; Tucci, C.E.M.; Paz, A.R. Uncertainty in climate change impacts on water resources in the Rio Grande basin, Brazil. Hydrol. Earth Syst. Sci. 2011, 15, 585-595. [CrossRef]

56. Huang, S.; Zang, W.; Xu, M.; Li, X.; Xie, X.; Li, Z.; Zhu, J. Study on runoff simulation of the upstream of Minjiang River under future climate change scenarios. Nat. Hazards 2015, 75, S139-S154. [CrossRef]

57. Parkinson, S.C.; Djilali, N. Robust response to hydro-climatic change in electricity generation planning. Clim. Chang. 2015, 130, 475-489. [CrossRef]

58. Jakeman, A.J.; Hornberger, G.M. How much complexity is warranted in a rainfall-runoff model? Water Resour. Res. 1993, 29, 2637-2649. [CrossRef]

59. Farinotti, D.; Usselmann, S.; Huss, M.; Bauder, A.; Funk, M. Runoff evolution in the Swiss Alps: Projections for selected high-alpine catchments based on ENSEMBLES scenarios. Hydrol. Process. 2011, 26, 1909-1924. [CrossRef]

60. Huss, M.; Farinotti, D.; Bauder, A.; Funk, M. Modelling runoff from highly glacierized alpine drainage basins in a changing climate. Hydrol. Process. 2008, 22, 3888-3902. [CrossRef]

61. Liang, X.; Lettenmaier, D.P.; Wood, E.F.; Burges, S.J. A simple hydrologically based model of land surface water and energy fluxes for general circulation models. J. Geophys. Res. Atmos. 1994, 99, 14415-14428. [CrossRef]

62. Widmann, M.; Bretherton, C.S.; Salathé, E.P., Jr. Statistical precipitation downscaling over the northwestern united states using numerically simulated precipitation as a predictor. J. Clim. 2003, 16, 799-816. [CrossRef]

63. Sieber, J.; Purkey, D. WEAP: Water Evaluation and Planning System; User Guide; Technical Report; Stockholm Environment Institute, U.S. Center: Somerville, MA, USA, 2015; Available online: www.weap21.org/ downloads/WEAP_User_Guide.pdf (accessed on 5 June 2016).

64. Yates, D.; Sieber, J.; Purkey, D.; Huber-Lee, A. WEAP21-A demand-, priority-, and preference-driven water planning model. Part 1: Model characteristics. Water Int. 2005, 30, 487-500. [CrossRef]

65. Kling, H.; Stanzel, P.; Preishuber, M. Impact modelling of water resources development and climate scenarios on Zambezi River discharge. J. Hydrol. Reg. Stud. 2014, 1, 17-43. [CrossRef]

66. Abera, F.F.; Asfaw, D.H.; Engida, A.N.; Melesse, A.M. Optimal operation of hydropower reservoirs under climate change: The case of Tekeze reservoir, Eastern Nile. Water 2018, 10, 273. [CrossRef]

67. Collischonn, W.; Tucci, C.E.M. Simulação hidrológica de grandes bacias. Rev. Bras. Recur. Hídricos 2001, 6, 95-118. (In Portuguese)

68. IPCC. Intergovernmental Panel on Climate Change. SRES Emissions Scenarios. Available online: http: / / sedac.ipcc-data.org/ddc/sres/index.html (accessed on 8 June 2016).

69. IPCC. Intergovernmental Panel on Climate Change. Scenario Process for AR5. Available online: http: //sedac.ipcc-data.org/ddc/ar5_scenario_process/RCPs.html (accessed on 1 April 2018).

70. Luz, M.P.; Beevers, L.C.; Cuthbertson, A.J.S.; Medero, G.M.; Dias, V.S.; Nascimento, D.T.F. The mitigation potential of buffer strips for reservoir sediment yields: The itumbiara hydroelectric power plant in Brazil. Water 2016, 8, 489. [CrossRef]

71. Schmidt, J.; Cancella, R.; Pereira, A.O., Jr. An optimal mix of solar PV, wind and hydro power for a low-carbon electricity supply in Brazil. Renew. Energy 2016, 85, 137-147. [CrossRef]

(C) 2018 by the authors. Licensee MDPI, Basel, Switzerland. This article is an open access article distributed under the terms and conditions of the Creative Commons Attribution (CC BY) license (http:/ / creativecommons.org/licenses/by/4.0/). 